\title{
PRAGMATIC KNOWLEDGE FOR SECOND LANGUAGE LEARNERS
}

\author{
Margana \\ State University of Yogyakarta
}

\begin{abstract}
To maximally acquire the target language, second language learners are demanded to master the knowledge of pragmatics on the grounds that it facilitates them to capture a comprehensive understanding of the classroom communication patterns which deal with how language is used according to its context. Added to this, knowledge of pragmatics can be used to minimise miscommunication and misunderstanding of the speech acts used in classroom communication practices. More specifically, second language learners have to acquire the issues of pragmatics which include types of illocutionary acts, illocutionary force, and implicatures. Such aspects of pragmatics are commonly found in classroom communication practices which are done by English teachers of secondary school levels. In reference to these issues, this paper attempts to review the types of illocutionary acts, illocutionary forces and conversational implicatures applied by English teachers of secondary school levels. Such an understanding of those three aspects of pragmatics is believed to facilitate students of secondary schools as the second language learners to easily make sense of the utterances as performed by English teachers in a series of English language teaching and learning practices.
\end{abstract}

Key words: speech act, illocutionary acts, illocutionary force, implicature

\section{INTRODUCTION}

In Indonesia, English serves twofold functions, namely as a content subject which is officially taught from the secondary school level to tertiary one and as a means of classroom instructions in the process of English language teaching and learning (Margana, 2004). The use of English as a means of classroom instruction 
relies on Acts of Indonesian Republic Number 24 Year 2009, Verse 25 (3) which states that English can be a device of classroom instruction of teaching the target language (English). This means that English teachers of secondary school levels are encouraged to use English in classroom communication practices on the grounds that it provides English exposure which could facilitate students to maximally gain the target language. This is supported by Ellis (2003) advocating that use of English in classroom communication provides second language learners (including secondary school students in Yogyakarta) with English exposures which become one of the determining factors to the success of acquiring the target language as maximal as possible. This leads to raising an assumption that having sufficient English exposures could facilitate students of secondary school levels to successfully gain the target language. For this reason, some English teachers of secondary schools in Yogyakarta tend to use English exclusively in classroom communication practices as performed in a series of English language teaching and learning starting from opening to closing.

The exclusive use of English by English teachers of secondary schools as a means of classroom communications as reflected through their speech acts potentially creates misunderstanding on the part of students when the students have insufficient knowledge of how English is used in context which is called knowledge of pragmatics. For example, the expression "Take one, pass them on" to some extent confuses some students of secondary schools who are not familiar with the form of illocutionary acts and illocutionary forces. In terms of the type of the illocutionary acts, the expression is categorized as a directive which means asking students to make an action. In terms of the illocutionary force, the expression means that the English teacher commands students to take one of the given copies and then give the other copies to the other students. The utterance "why didn't you study last night" has two interpretations. The first interpretation is that the English teacher wants to know the reason why the student did not study the material. The second interpretation is that the English teacher suggests that students should study before they join the English class in order that they do not find difficulty to join the English lesson. Such pragmatic knowledge is of great importance for students of secondary school levels in order to minimize some possible mis-interpretations which lead to having communication barriers between English teachers and students in classroom communication practices. This directly or indirectly determines the failure of acquiring the target language. 
In reference to the above issue, it is necessary that students of secondary school levels are familiar with the use of the speech acts by English teachers in classroom communication practices. To do so, they should have sufficient pragmatic knowledge, particularly the types of illocutionary acts and illocutionary forces as reflected in the utterances of the English teachers during classroom communications. Added to this, they should also gain sufficient knowledge of interpreting the implied meaning of the utterances expressed by the English teachers under the issue of the conversational implicatures. In short, students of secondary school levels are demanded to have pragmatic awareness which is believed to be fruitful to deal with classroom communication practices with their teachers. Bardovi-Harlig and Mahan-Taylor (2003) state that the pragmatic awareness facilitates students to fully participate in the English classroom communication. Failure to do this may cause learners to miss key points in what is communicated to them or make the others misunderstand what they themselves want to communicate (Thomas in Noureddine, 2007).

\section{THE IMPORTANCE OF PRAGMATICS KNOWLEDGE}

The importance of the pragmatics knowledge in English language teaching and learning has been advocated by many experts. For example, Demerezen (1991) claims that the pragmatic competence contributes to maximally acquire of the target language. He advocates that the pragmatic competence should be embedded in English language teaching on the grounds that it contributes to analyzing the use of language in context. Further, he urges that the cash value of words is not only dependent on usage but also on different registers of language such as situational settings, colloquial usage, jargons and others that heavily depend on context. Noureddine (2007) also advocates that the pragmatic issues such as speech acts, cooperative principle and the like should be explicitly presented in teaching the target language. He further states that the use of the pragmatic analysis confers pedagogical implications one of which is to provoke a sense of language awareness on the part of the students to deal with the essence of language use.

The mastery of pragmatic knowledge confers some important points to students of secondary school levels. The important points include determining communication strategies used to deal with some communicative functions such as responding to their English teachers' questions, suggestions, commands and the 
like which are appropriate to the context. According to Eslami-Rasekh (2005: 200), pragmatic competence that embodies illocutionary competence and sociolinguistic competence provides students with the ability o appropriately choose communicative acts and strategies to apply them depending on the contextual features of the situation. In suuport of this, pragmatic knowledge, which deals with understanding how words and utterances are used in context function play an important role as the vehicles of making interpretation of the speakers' intentions in communicative events such as classroom communication practices (Gómez et al., 2009: xiii). Added to this, pragmatic knowledge serves a very important role in the production and perception of the language. This implies that students of secondary schools as the interlocutors should have enough pragmatic knowledge to produce and perceive the proper and intended speech acts applied in classroom communication practices.

In relation to the above statements, it is evident that pragmatic competence is fruitful as it reveals the real use of language in context. The analysis can cope with possible communication barriers in the process of English language teaching and learning that leads to the failure of the acquisition of the target language. In order to get further understanding of the issue of the pragmatic analysis, the following discusses the nature of the pragmatics as the framework to deal with the speech acts expressed by the English teachers of secondary school levels in Yogyakarta.

\section{THE NOTION OF ILLOCUTIONARY ACTS AND ILLOCUTIONARY FORCE}

The term pragmatics is widely employed by many experts to refer to the study of language in context. Nourreddine (2007) states that pragmatics deal with analyzing the formal aspects of language with the appropriate context or accounting for the relationship between language forms and language users. The appropriate context means knowing when to speak, when not to speak, what to talk about, with whom to speak, where to speak, and in what manner to speak (Hymes in Nourreddine (2007). This suggests that pragmatics is concerned with the study of the meaning of speech acts or utterances in context (Demerezen, 1991) not the study of the meaning of the constructions as called semantics.

Leech (1983: 199), based on Austin?s categorization, categorizes speech acts into three distinct levels of action beyond the act of utterances, which include, 
locutionary, illocutionary, and perlocutionary acts. Locutionary acts refer to the basic act of an utterance or a meaningful linguistic expression (Yule, 1996:48). It is manifested in the form of words, phrases, clauses, or sentences which are constrained by grammatical rules and meanings. Illocutionary acts are defined as the intentions of the utterances as reflected in the locutionary acts (Finegan, et al., 1997:346). In line with this definition, Cuting (2008: 14) states that illocutionary acts refer to what the speakers are doing with their words. The third part of speech acts is perlocutionary acts. It is defined as the effect of the act on the hearer. Cuttings (2008:14) states the perlocutionary acts refer to the effect of a speaker's utterances on the hearer or the hearer's reaction to the speakers utterances. Those issues are under the discussion of pragmatics.

In lieu with the illocutionary acts, Searle in Finch (2000:182) classifies the illocutionary acts into five types, namely (1) representative, (2) directive, (3) comissive, (4) expressive, and (5) declarative. The term representative is defined as one of the illocutionary acts which commits the speaker to the truth of the uttered proposition. It is commonly used to represent a state of affairs (Finegan et al., 1997:L344). Such a type of the illocutionary acts is divided into some illocutionary forces which include stating, suggesting, boasting, complaining, claiming, and announcing (Leech, 1983:105). Further, Cutting (2008:14) adds some illocutionary forces of the representative, namely describing, hypothesizing, insisting, and predicting.

The second type of the illocutionary acts is directive, which is defined as asking the hearer to do something. With the use of directive, the addresser attempts to get the addressee to do some actions as he/she wants. This illocutionary act is subdivided into some types which include (1) commanding, (2) requesting, (3) suggesting, (4) inviting, (5) questioning, and (6) warning. The term commissive refers to committing the addresser to some future course of actions. In other words, it deals with an action which will be or will not be done in the future course. This illocutionary act is categorized into some illocutionary forces which include (1) promising, (2) vowing, (3) offering, (4) threatening, and (5) refusing.

The fourth illocutionary act is expressive. It is defined as a speech act which expresses a psychological state. This can be in the form of stating pleasure, pain, likes, dislikes, anger, joy, sorrow, and the like. The illocutionary act of expressive has some illocutionary forces such as (1) greeting, (2) thanking, (3) apologizing, (4) complimenting, (4) stating pleasure, (5) stating pain, (6) stating doubt, (7) 
stating confusion, (8) stating surprise, (9) stating panic, (10) stating anger, and (11) stating dislike.

Another type of the illocutionary act is declarative. It refers to a speech act of which effects immediately change an institutional state of affairs. Added to this, it tends to rely on elaborated extra-linguistic institutions. This illocutionary act comprises some illocutionary forces which include (1) excommunicating, (2) declaring war, (3) christening, (4) marrying, (5) firing from employment, and others Finch (2000:182).

With regard to the above issues, illocutionary acts are essential to be understood by students of secondary schools the illocutionary acts serve as the centre of speech acts which contain the intention of the acts. The failure of the communication is mainly determined by the success of making sense of the illocutionary acts as reflected in the form of the illocutionary forces. In lieu with this, the following present some examples of illocutionary acts and illocutionary forces used in classroom communication practices.

\section{ILLUCOTIONARY ACTS AND ILLUCOTIONARY FORCES IN ENGLISH CLASSROOM COMMUNICATION PRACTICES}

The following presents the examples of illocutionary acts and illocutionary forces which are used by English teachers of secondary schools levels in classroom communication practices. The examples of those two aspects of pragmatics were gained when the writer was involved in classroom observations at secondary school levels to capture the use of English in classroom communication practices. The discussion of the illocutionary acts excludes declaratives as the act of directives is only concerned with an institutional state of affairs.

\section{Representatives}

In the process of English language teaching. English teachers of secondary schools in Yogyakarta tend to perform the illocutionary act in the form of representatives. Such illocutionary act is sub-divided into some illocutionary forces. They include (1) stating, (2) informing, (3) agreeing, (4) arguing, (5) explaining, (6) describing, (7) convincing, (8) predicting, (9) reporting, and (10) stating opinions. The following presents the example of the illocutionary forces which are used by English teachers of secondary school levels. 


\section{a. Stating an opinion}

Stating an opinion is one of the illocutionary forces which is commonly employed by English teachers of secondary school levels. The following presents the examples of stating an opinion as shown in the bold forms.

$\mathrm{T}$ : Both Andika and Ruli made the same mistake in creating passive and active sentence. What is that, Andika said that Gita was ripped the book. Is it right? Gita was ripped the book? And Ruli said the book ripped Gita.

\section{b. Informing}

Informing is also used by English teachers of secondary schools to inform what students are going to do in the process of English language teaching and learning. The following presents the example of the illocutionary force in the form of informing as displayed in the bold forms.

$\mathrm{T}$ : And today, I will give you an example, a conversation. I and Mas Tri Budi will have a conversation. And after that, you have to answer the questions on the whiteboard.

\section{c. Agreeing}

In the process of English language teaching and learning, English teachers of secondary schools utilize agreeing as one of the illocutionary forces. It is employed to express their opinions to support students' ideas as exemplified below.

$\mathrm{T}$ : Ya, I think your opinion is the same with me, but there is one key that I don't explain you yet, ya. And actually, I agree with your opinion based on the text. Actually our reason is based on the text, not out of the text, and add with your opinion and involve our opinion in the class.

\section{d. Arguing}

English teachers also employ the illocutionary force of arguing to deal with different ideas or opinions with their students. The following presents the example of arguing used in the process of English language teaching and learning as shown in the bold form. 
$\mathrm{T}$ : What kind of plant do you have? Rambutan, banana, jambu, dondong, kelapa, flower. Okay, what do you call a short plant that we grow in pots? A short plant.

$\mathrm{S}$ : Anthorium.

$\mathrm{T}$ : Anthorium? No, it is not anthorium. A short plant that we grow in pots? Do plants always grow in the ground? What do you think?

\section{e. Explaining}

One of the illocutionary forces of representatives used by English teachers of secondary schools is explaining. Such an illocutionary force is employed by English teachers to provide students with a clear explanation of the presented materials. The example of explaining is presented in the bold forms.

$\mathrm{T}$ : Ya, statement. Okay, that is the conclusion of the hortatory exposition and recommendation can be ought to happen or not to happen for the writer's position that is mentioned from the thesis paragraph. And then, you must know that the tense in hortatory exposition is Present Tense. You have new text, and then, before this, you have learned for about 3 texts of hortatory exposition, ya?

\section{f. Describing}

In the process of English language teaching and learning, English teachers of secondary schools utilize describing as one of the illocutionary forces. It is employed to confer a description of a particular issue that exists in the topics as displayed in the bold forms.

$\mathrm{T}$ : Lizzy? Who is Lizzy.

$\mathrm{S}$ : George's girlfriend.

$\mathrm{T}$ : George's girlfriend. How does Lizzy look like?

$\mathrm{S}$ : She is slim, not too tall, not too short, wavy hair.

$\mathrm{T}$ : Okay, slim, not too tall, not too short, wavy hair. Beautiful wavy hair, like you? And then? 


\section{g. Convincing}

English teachers of secondary schools use the illocutionary force in the form of convincing. This is employed to ascertain some utterances made by English teachers. The following presents the examples of the illocutionary force of convincing.

$\mathrm{T}$ : Okay good. I think the answers are like that. Maybe I will continue the next materials, and the second task. Any five drafts, so I will divide four groups ya. How many students are in the class?

\section{h. Predicting}

English teachers of secondary schools utilize the illocutionary force of predicting when they are involved in English language teaching and learning as exemplified below.

$\mathrm{T}$ : You have to take the remedy test. Most of you probably take the remedy next week. Jadi mungkin nanti ada beberapa yang harus mengulang, remidi. I think it's enough for today. See you next week.

\section{Directives}

English teachers are also believed to perform the illocutionary acts in the form of directives. The directive acts consist of some illocutionary forces which include (1) commanding, (2) requesting, (3) suggesting, (4) inviting, (5) questioning, and (6) warning. The following exemplifies each type of the illocutionary forces.

\section{a. Commanding}

Commanding is one of the illocutionary forces which is employed by English teachers of secondary schools when they are involved in the process of English language teaching and learning. It is used to ask their students to do something. The following presents the example of commanding in the form of imperative as performed in the bold form.

$\mathrm{T}$ : Listen to me! What you are going to do next is reading the text in front of readers and choose one that is easy for you to understand. Is that clear for you? Have you got the choice? 


\section{b. Requesting}

English teachers of secondary schools also use the illocutionary force of requesting in English language teaching and learning. They use some expressions like would you, could you, and the like to do with questing. It is employed to request the students to do something. The following presents the example of requesting.

$\mathrm{T}$ : Aris, maybe he has a different answer. Aris, would you please read louder?

$\mathrm{S}$ : (Mengulang membacajawabannya sendiri)

$\mathrm{T}$ : Hydroponics is unconventional growing plant and hello, do you hear me? Listen, please. Hydroponics is unconventional growing plant and technique, sorry, and don't need any soil. Number two. Who wants to answer number two? Who wants to answer number two? Number two. What do plants basically need? Adnan, could you read it again?

\section{c. Suggesting}

In the process of English language teaching and learning, the illocutionary force of suggesting is also employed by English teachers of secondary schools as shown in the bold forms. $q$

$\mathrm{T}$ : Okay, grammar. Any other? What make difficult for you? Okay vocabulary and grammar. Anything else? When you are reading the text, you may check the difficult words. Okay, when you go to the library, in the Jakarta Post please read the news and search many difficult words there. So I think it is better for you to read although you only read one news from Jakarta Post and try to analyze the vocabulary. Do you know what I mean?

$\mathrm{S}$ : Yes.

\section{d. Inviting}

Inviting is also employed by English teachers of secondary schools in the process of English language teaching and learning as exemplified in the bold forms.

$\mathrm{T}$ : Okay, good! A hydroponics tomato plant produces more than a soil grown tomato plan. The next is number six. Who wants to answer number six? Yes, please.

$\mathrm{S}$ : Everything is carefully controlled in a greenhouse. 


\section{e. Questioning}

English teachers of secondary schools also employ the illocutionary force in the form of questioning. The following presents the examples of the illocutionary force of questioning.

$\mathrm{T}$ : Good! I want to ask you about plants. Have you ever grown any plants around your house?

S : Yes.

$\mathrm{T}$ : What kind of plant do you have? Rambutan, banana, jambu, dondong, kelapa, flower. Okay, what do you call a short plant that we grow in pots? A short plant.

\section{f. Warning.}

The illocutionary force of warning is also employed by English teachers of secondary schools in the process of English language teaching and learning as exemplified in the bold forms.

$\mathrm{T}$ : Do you understand about the questions?

$\mathrm{S}$ : Yes.

T : Don't forget to write the generic structure in the text like this. Where is thesis, where is an argument, and where is reiteration on the text.

\section{Commissives}

The illocutionary act of commissives is also employed by English teachers of secondary schools when they are involved in the process of English language teaching and learning. The illocutionary act of commissives embodies three types of the illocutionary forces that include (1) promising, (2) offering, and (3) threatening. Each type of the illocutionary forces is presented below.

\section{a. Promising}

English teachers of secondary schools also utilize promising in the process of English language teaching. The following performs the example of the use of promising. 
$\mathrm{T}$ : There are many students maybe have to pass the remedy test. Okay, I will announce the result after the lesson, ya. Are you ready now?

S : Yes.

\section{b. Offering}

Offering is also employed by English teachers of secondary schools in the process of English language teaching and learning as exemplified below in the bold form.

$\mathrm{T}$ : Angga, do you want to write the answer number ten? Okay, thank you very much. Number one. How about the sentence here? Aneh? The percentage of the earth which is not covered by water is 30 percent.

\section{c. Threatening}

To keep a discipline of students, English teachers of secondary schools use threatening. Such an illocutionary force is employed to educate students in order that they obey the existing rules. Below is the example of threatening used in classroom activities.

T : I will give you the result of the English test after the class. Nanti ya, nanti akan saya bagikan hasilnya. All the scores are very terrible. Tapi keseluruhan buruk!

S : Yah...

$\mathrm{T}$ : So, you must study hard from now on! Kalian harus kerja keras mulai dari sekarang. You have only three months. Otherwise, you will fail. Kita hanya punya waktu 3 bulan lagi.

\section{Expressives}

The expressive illocutionary act is also utilized by English teachers of secondary school levels. The illocutionary act of expressive consists of some illocutionary forces. They include (1) greeting, (2) thanking, (3) apologizing, (4) complimenting, (5) stating pleasure, (6) stating doubt, (7) stating confusion, (8) stating surprise, (9) stating panic, (10) stating anger, and (11) stating dislike. The following presents each type of the illocutionary forces of the expressives. 


\section{a. Greeting}

Greeting is one of the illocutionary forces of the expressive which is used by English teachers of secondary schools when they are involved in the process of English language teaching and learning. The following presents the example of greeting.

$\mathrm{T}$ : Morning students.

$\mathrm{S}$ : Morning, Ma'am.

$\mathrm{T}$ : How are you today?

$\mathrm{S}$ : Fine.

\section{b. Thanking}

English teachers of secondary schools also utilize thanking in the process of English language teaching. It is used to appreciate what their students do. The following performs the examples of the use of thanking.

$\mathrm{T}$ : Very good! Thank you, Mela. And, Ronald finds politics interesting. Febriana. Yes, please. Ronald? What is interesting here?

$\mathrm{S}$ : Menarik

$\mathrm{T}$ : Menarik, Thank you. Joining politics is interesting. He is interested in politics. What about this?

\section{c.Apologizing}

The illocutionary force of apologizing is also employed by English teachers of secondary schools as exemplified in the bold forms.

$\mathrm{T}$ : Okay, we have finished to answer. Kristi have you finished to answer?

S : Notyet.

$\mathrm{T}$ : Eko, have you finished to answer?

$\mathrm{S}$ : Yes.

$\mathrm{T}$ : Okay, please answer number one. Sorry number eight. Sorry read the questions, first. 
The following also presents the illocutionary force of apologizing in classroom communication practices by English teachers of secondary school levels.

$\mathrm{T}$ : Louder please. What did you say?

$\mathrm{S}$ : (Siswa mengulangi mengkoreksi halaman dari materi mid test yang disampaikan guru)

$\mathrm{T}$ : Sorry, sorry I have a mistake, sorry, sebentar saya carikan halamannya $y a$, itu salah. Is there anyone who can find? Ada yang bisa menemukan? Sorry, on page 132. Okay thank you very much for your correction. Finished?

\section{d. Complimenting}

The illocutionary force of complimenting is also used in the process of English language teaching and learning. Below is the example of complementing used in English classroom communication.

$\mathrm{T}$ : Good, give applause. The next Eko's group?

$\mathrm{S}$ : Notyet.

$\mathrm{T}$ : Nita's group. A part sebagian-sebagian, time is limited waktunya terbatas, don't worry to make mistakes jangan takut salah, please.

\section{e. Stating pleasure}

In the process of English language teaching and learning, the illocutionary force of stating pleasure is also employed by English teachers of senior high schools. The following presents the example of the illocutionary force of stating pleasure.

$\mathrm{T}:$ Are you ready to start the lesson?

$\mathrm{S}$ : Yes.

$\mathrm{T}$ : Yes? Who is missing today? Who is missing today? Who is absent today?

$\mathrm{S}$ : Nobody absent.

$\mathrm{T}$ : Nobody? Great. 


\section{f. Stating doubt}

English teachers of secondary schools utilize stating doubt in the process of English language teaching. The following performs the example of the use of stating doubt.

$\mathrm{T} \quad$ : So, you talk about the glass-nya? Glass-nya memantulkan sinar matahari? Okay, I will ask this to your Biology teacher, what is greenhouse.

\section{g. Stating confusion}

The illocutionary force of stating confusion is found in the process of English language teaching and learning. Below is the example of stating confusion used in classroom communications.

$\mathrm{T}$ : Triggering? What is that? What is trigger? It happens suddenly. Okay. Suddenly happen. What else? Pandemic. So what is pandemic? Do you know pandemic. You can look at in the dictionary if you do not know. How many students who bring dictionary? One two three four. Only four students. Five? So what is pandemic? Hello? Asnan. What is pandemic?

\section{h. Stating surprise}

Stating surprise is one of the illocutionary forces of the expressive which is used by English teachers of senior high schools. The following presents the example of stating surprise gathered from the respondents.

$\mathrm{T}$ : What do you say in Bahasa Indonesia? I burnt my finger. I burnt my finger.

$\mathrm{S}$ : Sayamembakartangan.

$\mathrm{T}$ : Oo..saya membakar tangan saya? Oh, no! Aduh teneh nek membakar tangan kita yo? Sakit. What do you say? I burnt my finger. I burnt my finger.

\section{i. Stating panic}

The illocutionary force of stating panic is used by English teachers of senior high schools. The following presents the example of stating panic as shown in the bold forms. 
$\mathrm{T}:$ Hem. You know what is pandemy?

$\mathrm{S}$ : Endemic.

$\mathrm{T}$ : Okay, endemic. What is endemic? What is endemic? What is endemic? Apa mbak Risty. What is endemic?

$\mathrm{S}$ : Menyerang.

\section{j. Stating anger}

Stating anger is one of the illocutionary forces of the expressive used in classroom communication practices. They use such an illocutionary force to deal with classroom management as shown in the bold forms below.

$\mathrm{T}$ : How many students who do not bring dictionary? How many? So many. Almost. Why don't you bring dictionary? Is it not necessary for you? Okay. Once again I ask you when you are in the English class you have to bring your dictionary, ya. So the teacher, what is it, when I ask you to find difficult words you can look up in the dictionary. You do not need to wait your teacher. You can open it by yourself.

\section{k. Stating dislike}

The illocutionary force of stating dislike is found in the process of English language teaching and learning as performed by English teachers of senior high schools. Below is the example of stating dislike used in English classroom communication practices.

$\mathrm{T}$ : Susanto, could you help please? Mbak Erma, please give me your opinion? Please try. Please express your idea? Express your idea.

S : Siswa merespon perintah guru.

$\mathrm{T}$ : Is it only that? Does anyone to add? Ferino is very famous because of her sexies beauty or appearance maybe? What is the background event? What is the background event? 


\section{TYPES OF IMPLICATURES}

In classroom communication practices, English teachers of secondary school have intentional meanings which are not explicitly stated in their utterances. This drives the students to struggle hard to get the message which is implicitly stated in order to minimize communication barriers due to the unsaid information. The implicit message in a conversation is called an implicature. Brown and Yule (1983: 31) state that an implicature is what the speaker can imply, suggest, or mean as distinct from what the speakers literally express. As it is not explicitly stated by speakers in their utterances, the hearers then need to make implication or suggestion in order to gain what the speakers mean through their utterances. Further, Horn and Ward (2006:3) state that implicature is a component of speakers' meaning that constitutes an aspect of what is meant in the speakers' utterance without being part of what is said. Grundy (2008: 92) claims that an implicature is a meaning that is conveyed, but not explicitly stated. To know the intended meaning of the speakers' utterances, the hearers must do a deep interpretation since the speakers' utterances usually have more than a literal meaning.

In terms of the types of implicatures, some experts classify the implicatures into two types, namely (1) conversational implicatures and (2) conventional implicatures. The conversational implicatures refer to a particular meaning as implicitly conveyed by the speaker in conversational practices (Cutting, 2008:35). In this case, the hearers are demanded to make an inference of the speakers' utterances. This type of implicatures is divided into two, namely (1) generalized conversational implicatures and (2) particularized conversational implicatures. The former may arise without any particular context or special scenario to deal with additional conveyed meaning (Yule, 1996:41). For example, the construction I saw a university student last Monday standing next to a pretty car exemplifies the generalized conversational implicature which informs that the student and the pretty car do not belong to the speaker. The latter deals with an implicature that requires very specific contexts in which inferences are needed. Such inferences are required to search out the conveyed meanings. The following presents the example of the particularized conversational implicature.

John : May I have a ride tomorrow? My car is broken.

Yesica : My mother asks me to take her in the airport at dawn. 
The above conversation shows that Yesica could not give a ride to John because she takes her mother in the airport. Such an inference requires particular contexts to interpret the implied meaning.

Different to the conversational implicature, the conventional implicature deals with specific words and results in additional conveyed meanings when the words are employed (Yule, 1996:45). Mey (1993;104) urges that the conventional implicature cannot be changed by invoking another context as it is standardized by convention. Levinson (1983: 127) claims that the conventional implicature is treated as non-truth-conditional inferences which are not generated from superordinate pragmatic principles like the maxims, but it is simply connected by conversation to particular lexical item. This suggests that such a type of the implicatures can be automatically interpreted by words as literally expressed without occurring in conversations and not depending on special contexts for its interpretation. For example, the word and in My mother ask me to buy apples and oranges means additional as the word and is a conjunction that links some similar items. In this case, it does not need a particular context to interpret the meaning of the word and.

In reference to the above discussions, the speech acts as expressed by English teachers in class communication practices also constitute implied meanings which, to some extent, lead to mis-interpretation on the part of the students. Such implied meanings should be comprehensively analyzed under the issue of conversational implicatures as a part of the pragmatic analysis. For such reasons, the following presents the examples of the conversational implicatures which appear in classroom communication practices at secondary school levels.

\section{EXAMPLES OF CONVERSATIONAL IMPLICATURES IN CLASSROOM COMMUNICATION PRACTICES}

As mentioned earlier, English teachers of secondary schools performed two types of conversational implicatures. They include generalized conversational implicature and particularized conversational implicature. Each is discussed below.

\section{Generalized Conversational Implicature}

In classroom communication practices, English teachers perform the generalized conversational implicature as exemplified below. 
$\mathrm{T}$ : Well, before we start our lesson today, let's we have our prayer. Please the leader of the class lead the prayer.

$\mathrm{S}$ : Before we start our study, it is better for us to pray together. Lets pray.

In reference to the above example, the speaker confers an implied meaning as shown in the bold forms. She asks one of the students who serves as the leader of the class to lead saying a prayer before starting the lesson. Such an implied meaning is categorized as the generalized conversational implicature as the hearers do not need to apply specific knowledge to make sense of such utterances. See the other example below.

$\mathrm{T}$ : When we are talking about report texts, we are discussing the generic structure of reporting or report. What is the generic structure of the report text?

S : Title.

The example above shows that the English teacher has an implied meaning through the uttered expressions. She asks students to mention the pattern of the report text which fixedly consists of two items, namely general classification and identification. The implied meaning is also classified as the generalized conversation implicature as it does not require a specific context to make sense of the used utterances.

\section{Particularized Conversational Implicature}

The illocutionary acts performed by English teachers have particularized conversational implicature as exemplified below.

$\mathrm{T}$ : Pandemic. So what is pandemic? Do you know pandemic. You can look at in the dictionary if you do not know. How many students who bring dictionary? One two three four. Only four students. Five? So what is pandemic? Hello? Asnan. What is pandemic? Why don't you look up in your dictionary if you do not know?. What is that? Gak ada? What is that?

$\mathrm{S}$ : Kekacauan.

The above example performs that the teacher suggests that Asnan should look up the meaning of the difficult word in the dictionary. To interpret such an utterance shown in bold forms requires a particular context the utterance can be interpreted asking Asnan why he did not find the meaning of the difficult word in the dictionary. See the other example below. 
$\mathrm{T}$ : How many students who do not bring dictionary? How many? So many. Almost. Why don't you bring dictionary? Is it not necessary for you? Okay. Once again I ask you when you are in the English class you have to bring your dictionary, ya. So the teacher, what is it, when I ask you to find difficult words you can look up in the dictionary. You do not need to wait your teacher. You can open it by yourself.

In reference to the above example, the teacher gets angry with the students because students are not independent. The utterances performed by English teachers encourage students to be independent. This requires students to make sense of the utterances with the use of particular knowledge categorized as the particularized conversational implicature.

\section{Note:}

$\mathrm{T}: \quad$ English Teacher

S : $\quad$ Student

\section{CONCLUSIONS}

The above discussion shows that there are four types of illocutionary acts: representatives, directives, commissives, and expressives. Each of the illocutionary acts is classified in terms of its illocutionary forces. Added to this, English teachers also present the implied meanings as manifested in their utterances which are called the conversational implicatures embodying the generalized conversational implicatures and particularized conversational implicatures.

With regard to the examples explored, the speech acts uttered by English teachers in classroom communication practices are complex in nature on the grounds that many types of speech acts and conversational implicatures are employed. This suggests that students of secondary schools should be familiar with the speech acts practised by English teachers. Knowing the types of speech acts and types of implicatures is of great importance to students to minimize misconception or misinterpretation of their English teachers' speech acts. 


\section{References}

Bardovi-Harlig, K. \& Mahan-Taylor R. (2003). Introduction to Teaching Pragmatics. In English Teaching Forum Vol.41/No. 3, pp. 37-44

Bardovi-Harlig, K. \& Mahan-Taylor, R. (2003). Teaching Pragmatics. Washington DC: US Department of State, Office of English Language Programs

Bardovi-Harlig, K. (2001). Evaluating the empirical evidence: Grounds for instruction in pragmatics? In G. Kasper \& Rose, K. R. (Eds.). Pragmatics in Language Teaching. Cambridge: CUP

Bogdan, R. and S.J. Taylor. (1975). Introduction to Qualitative Research Method. Canada: John Wiley \& Sons.

Cutting, J. (2008). Pragmatics and Discourse: a Resource Bookfor Students. New York: Routledge.

Ellis, Rod (2003). The Study of Second Language Acquisition. UK: Oxford University Press.

Eslami-Rasekh, Z. (2005). Raising the pragmatic awareness of language learners. ELT Journal, Volume 59/3.

Finch, G. (2000). Linguistic Terms and Concepts. London: Mac Millan Press Ltd.

Finnegan, E., Blair, D. \& Collin, P. 1997. Language: Its Structure and Use. 2nd Ed. Australia: Harcourt Brace \& Co.

Gómez, R.M.et al. (2009) Pragmatics Applied to Language Teaching and Learning. Cambridge:Cambridge Scholars Publishing.

Grundy, P. (2008). Doing Pragmatics. London: Hodder Education.

Horn, L.R. and G. Ward. (2006). The Handbook of Pragmatics. Oxford: Blackwell Publisher.

Kasper G. (2001). Classroom research on Interlanguage Pragmatics. In G. Kasper \& Rose, K. R. (Eds.) Pragmatics in Language Teaching. Cambridge: CUP

Leech, G. (1983). Principles of Pragmatics. New York: Addison Wesley Longman Publishing

Levinson, S. 1983. Pragmatics. Cambridge: Cambridge University Press. 
Margana. (2004). The Functions of Code-switching Practised by English Teachers and Students of Junior High Schools of Yogyakarta. Proceeding International Conference at National University of Singapore.

Mey, J.L. (1993). Pragmatics: An Introduction. Massachusetts: Best-set Typesetter Ltd.

Silva, A. J. (2003). The Effects of Instruction on Pragmatic Development: Teaching Polite Refusals in English. Second Language Studies, 22(1), Fall 2003, pp. 55-106.

Yule, G. (1996). Pragmatics. Oxford: Oxford University Press. 